medRxiv preprint doi: https://doi.org/10.1101/2022.01.04.22268737; this version posted January 5, 2022. The copyright holder for this preprint

(which was not certified by peer review) is the author/funder, who has granted medRxiv a license to display the preprint in perpetuity.

This article is a US Government work. It is not subject to copyright under 17 USC 105 and is also made available

CVD biomarkers and kidney function

\title{
Cardiovascular disease protein biomarkers are associated with kidney function: the Framingham Heart Study
}

Amena Keshawarz, PhD, MPH; ${ }^{\text {a,b }}$ Shih-Jen Hwang, PhD; ${ }^{\mathrm{a}, \mathrm{b}}$ Gha Young Lee, BS; ${ }^{\mathrm{a}, \mathrm{b}}$ Zhi Yu, MB, PhD; ${ }^{\mathrm{c}, \mathrm{d}, \mathrm{e}}$ Chen Yao, PhD; ${ }^{\mathrm{a}, \mathrm{b}}$ Anna Köttgen, MD, MPH ${ }^{\mathrm{f}, \mathrm{g}}$; Daniel Levy, MD ${ }^{\mathrm{a}, \mathrm{b}}$

Affiliations:

${ }^{a}$ Population Sciences Branch, Division of Intramural Research, National Heart, Lung, and Blood Institute, National Institutes of Health, Bethesda, MD, USA

${ }^{\mathrm{b}}$ Framingham Heart Study, Framingham, MA, USA

${ }^{\mathrm{c}}$ Broad Institute of Harvard and MIT, Cambridge, Massachusetts

${ }^{\mathrm{d}}$ Department of Epidemiology, Johns Hopkins Bloomberg School of Public Health, Baltimore,

Maryland

${ }^{\mathrm{e}}$ Welch Center for Prevention, Epidemiology, and Clinical Research, Johns Hopkins University, Baltimore, Maryland

${ }^{\mathrm{f}}$ Institute of Genetic Epidemiology, Faculty of Medicine and Medical Center - University of Freiburg, Freiburg, Germany

${ }^{\mathrm{g}}$ Department of Epidemiology, Johns Hopkins Bloomberg School of Public Health, Baltimore, MD

Short title: CVD biomarkers and kidney function

Corresponding author:

Daniel Levy, MD, Framingham Heart Study

73 Mt. Wayte Avenue

Framingham, MA 01702 
medRxiv preprint doi: https://doi.org/10.1101/2022.01.04.22268737; this version posted January 5, 2022. The copyright holder for this preprint (which was not certified by peer review) is the author/funder, who has granted medRxiv a license to display the preprint in perpetuity.

This article is a US Government work. It is not subject to copyright under 17 USC 105 and is also made available

CVD biomarkers and kidney function for use under a CCO license.

Phone: (508) 872-6556

levyd@nih.gov

Number of tables: 3

Number of figures: 1

Abstract word count: 297

Body text word count: 3,890

Keywords: chronic kidney disease, cardiovascular disease, proteomics, Mendelian randomization 
medRxiv preprint doi: https://doi.org/10.1101/2022.01.04.22268737; this version posted January 5, 2022. The copyright holder for this preprint

(which was not certified by peer review) is the author/funder, who has granted medRxiv a license to display the preprint in perpetuity.

This article is a US Government work. It is not subject to copyright under 17 USC 105 and is also made available for use under a CCO license.

CVD biomarkers and kidney function

Background. Biomarkers common to chronic kidney disease (CKD) and cardiovascular

2 disease (CVD) may reflect early impairments underlying both diseases.

Methods. We evaluated associations of $71 \mathrm{CVD}-$ related plasma proteins measured in

$4 \quad$ 2,873 Framingham Heart Study (FHS) Offspring cohort participants with cross-sectional

5 continuous eGFR and with longitudinal change in eGFR from baseline to follow-up ( $\triangle \mathrm{eGFR}$ ).

6 We also evaluated the associations of the 71 CVD proteins with the following dichotomous

7 secondary outcomes: prevalent CKD stage $\geq 3$ (cross-sectional), new-onset CKD stage $\geq 3$

8 (longitudinal), and rapid decline in eGFR (longitudinal). Proteins significantly associated with

9 eGFR and $\triangle \mathrm{eGFR}$ were subsequently validated in 3,951 FHS Third Generation cohort

10 participants and were tested using Mendelian randomization (MR) analysis to infer putatively

11 causal relations between plasma protein biomarkers and kidney function.

Results. In cross-sectional analysis, 37 protein biomarkers were significantly associated

13 with eGFR at FDR $<0.05$ in the FHS Offspring cohort and 20 of these validated in the FHS Third

14 Generation cohort at $\mathrm{p}<0.05 / 37$. In longitudinal analysis, 27 protein biomarkers were

15 significantly associated with $\triangle \mathrm{eGFR}$ at FDR $<0.05$ and 12 of these were validated in the FHS

16 Third Generation cohort at $\mathrm{p}<0.05 / 27$. Additionally, 35 protein biomarkers were significantly

17 associated with prevalent CKD, five were significantly associated with new-onset CKD, and 17

18 were significantly associated with rapid decline in eGFR. MR suggested putatively causal

19 relations of melanoma cell adhesion molecule (MCAM; $-0.011 \pm 0.003 \mathrm{~mL} / \mathrm{min} / 1.73 \mathrm{~m}^{2}, \mathrm{p}=5.11 \mathrm{E}-$

20 5) and epidermal growth factor-containing fibulin-like extracellular matrix protein 1 (EFEMP1; -

$\left.210.006 \pm 0.002 \mathrm{~mL} / \mathrm{min} / 1.73 \mathrm{~m}^{2}, \mathrm{p}=0.0001\right)$ concentration with eGFR.

Discussion/Conclusions: Eight protein biomarkers were consistently associated with

23 eGFR in cross-sectional and longitudinal analysis in both cohorts and may capture early kidney 
medRxiv preprint doi: https://doi.org/10.1101/2022.01.04.22268737; this version posted January 5, 2022. The copyright holder for this preprint

(which was not certified by peer review) is the author/funder, who has granted medRxiv a license to display the preprint in perpetuity.

This article is a US Government work. It is not subject to copyright under 17 USC 105 and is also made available

CVD biomarkers and kidney function

24 impairment; others were implicated in association and causal inference analyses. A subset of

25 CVD protein biomarkers may contribute causally to the pathogenesis of kidney impairment and

26 should be studied as targets for CKD treatment and early prevention.

27 
medRxiv preprint doi: https://doi.org/10.1101/2022.01.04.22268737; this version posted January 5, 2022. The copyright holder for this preprint

(which was not certified by peer review) is the author/funder, who has granted medRxiv a license to display the preprint in perpetuity.

This article is a US Government work. It is not subject to copyright under 17 USC 105 and is also made available for use under a CCO license.

CVD biomarkers and kidney function

\section{Introduction}

Chronic kidney disease (CKD) affects approximately $15 \%$ of the United States population, including more than $30 \%$ of adults over the age of 65 years. ${ }^{1,2}$ Additionally, CKD is

31 among the leading global causes of mortality. ${ }^{3} \mathrm{CKD}$ is characterized by kidney damage and

32 impairment of filtration, which can culminate in kidney failure and death. ${ }^{4}$ Kidney function is

33 frequently assessed clinically using estimated glomerular filtration rate (eGFR) based on serum

34 creatinine concentration. ${ }^{5}$ Early stages of CKD are often asymptomatic, and as such, CKD may

35 not be diagnosed until the development of substantial and often irreversible kidney dysfunction.

36 Thus, the identification of biomarkers of subclinical CKD that detect early kidney impairment

37 when treatment is more likely to be beneficial could prove to be important for disease prevention

38 and treatment.

CKD and cardiovascular disease (CVD) share common risk factors including diabetes mellitus (DM) and hypertension, ${ }^{6}$ which are highly prevalent in adults with CKD and are

41 associated with subclinical and clinical CVD risk. ${ }^{7,8}$ More than $50 \%$ of CKD cases in the United

42 States are attributable to $\mathrm{DM},{ }^{9}$ and estimates of hypertension prevalence in patients with CKD

43 range between $40 \%$ and $60 \% .{ }^{10-12}$ Other shared mechanisms contributing to CKD and CVD

44 include inflammation, ${ }^{13}$ activation of the renin-angiotensin-aldosterone system, ${ }^{13}$ oxidative

45 stress, ${ }^{14,15}$ and endothelial dysfunction. ${ }^{14}$ Identifying biomarkers of kidney function may provide

46 insights into shared mechanisms of CKD and CVD.

47 Given the complex relationship between CKD and CVD, we aimed to identify protein

48 biomarkers of kidney dysfunction and CKD. To this end, we evaluated the associations of 71

49 CVD-related plasma proteins with CKD traits. These proteins were measured in 7,184

50 Framingham Heart Study (FHS) participants as a part of the Systems Approach to Biomarker 
medRxiv preprint doi: https://doi.org/10.1101/2022.01.04.22268737; this version posted January 5, 2022. The copyright holder for this preprint (which was not certified by peer review) is the author/funder, who has granted medRxiv a license to display the preprint in perpetuity. This article is a US Government work. It is not subject to copyright under 17 USC 105 and is also made available

CVD biomarkers and kidney function

51 Research in Cardiovascular Disease (SABRe CVD) Initiative. ${ }^{16}$ We tested the cross-sectional

52 and longitudinal associations of the 71 CVD proteins with kidney function traits. We also

53 conducted causal inference analyses using genetic variants associated with these proteins in

54 conjunction with genetic variants from a recently published large GWAS meta-analysis of

55 kidney function traits. ${ }^{17}$

56 Materials and Methods

57 Discovery sample

The discovery sample for this investigation included participants in the FHS Offspring ${ }^{18}$

59 cohort who attended the seventh examination cycle (1998-2001; baseline visit). At this visit,

60 serum and plasma samples were collected for measurement of serum creatinine and the 71 CVD-

61 related plasma proteins as part of the SABRe CVD Initiative. ${ }^{16}$ Participants with a baseline

62 eGFR $\geq 60 \mathrm{~mL} / \mathrm{min} / 1.73 \mathrm{~m}^{2}$ who attended the FHS Offspring eighth examination cycle (2005-

63 2008; follow-up visit) where a second serum creatinine measurement was obtained were

64 included in the longitudinal analysis of kidney function.

65 Participants with a medical record-confirmed diagnosis of heart failure or myocardial

66 infarction at the baseline visit were excluded due to the effect of these diagnoses on biomarker

67 concentrations, yielding a final sample of 2,873 participants for cross-sectional analysis. There

68 were 2,393 participants who attended the follow-up examination and were eligible for inclusion

69 in the longitudinal analyses. All study protocols were approved by the Boston University

70 Medical Center institutional review board, and all study participants provided their

71 informed consent to participate in FHS research investigations. An overview of the study design

72 is presented in Figure 1.

73 Clinical examination and definitions 
medRxiv preprint doi: https://doi.org/10.1101/2022.01.04.22268737; this version posted January 5, 2022. The copyright holder for this preprint

(which was not certified by peer review) is the author/funder, who has granted medRxiv a license to display the preprint in perpetuity.

This article is a US Government work. It is not subject to copyright under 17 USC 105 and is also made available

CVD biomarkers and kidney function

Medical history and fasting blood samples were collected from all study participants at an

75 in-person research center examination. ${ }^{19}$ Body mass index (BMI) was calculated as the ratio of

76 the participant's weight in kilograms to the square of height in meters. DM status was defined by

77 fasting blood glucose concentration $\geq 126 \mathrm{mg} / \mathrm{dL}$ or use of hypoglycemic medication. ${ }^{20}$

78 Hypertension was defined by systolic blood pressure $\geq 140 \mathrm{mmHg}$, diastolic blood pressure $\geq 90$

$79 \mathrm{mmHg}$, or use of antihypertensive medication. ${ }^{21}$ Participants were defined as current smokers if

80 they reported smoking at least one cigarette per day on average during the previous year.

81 Prevalent CVD at the baseline study visit was defined as angina pectoris, coronary insufficiency,

82 cerebrovascular accident, atherothrombotic infarction of brain, transient ischemic attack, cerebral

83 embolism, intracerebral hemorrhage, subarachnoid hemorrhage, or intermittent claudication.

$84 \quad$ SABRe CVD biomarkers

Details of measurement of the 71 CVD-related proteins evaluated in this study have been

86 described previously. ${ }^{16}$ Briefly, plasma samples were obtained from all participants at their

87 baseline clinical examinations and stored at $-80^{\circ} \mathrm{C}$. Samples were assayed and concentrations of

$88 \quad 85$ biomarkers were quantified using a modified ELISA sandwich approach on a Luminex xMAP

89 platform (Sigma-Aldrich, St. Louis, MO); 71 of these had detectable levels in at least $95 \%$ of

90 participant samples and were used in the present analyses. The 71 protein biomarkers used in this

91 study and their molecular weights are presented in Supplemental Table 1. Due to the

92 distribution of protein concentration values, inverse-rank normalized protein concentration

93 values were used in all statistical analyses.

$94 \quad$ Kidney function traits

95 Serum creatinine was measured using the modified Jaffe method (Roche Diagnostics,

96 Indianapolis, IN) and calibrated to National Health and Nutrition Examination Survey 
medRxiv preprint doi: https://doi.org/10.1101/2022.01.04.22268737; this version posted January 5, 2022. The copyright holder for this preprint (which was not certified by peer review) is the author/funder, who has granted medRxiv a license to display the preprint in perpetuity. This article is a US Government work. It is not subject to copyright under 17 USC 105 and is also made available

CVD biomarkers and kidney function

97 (NHANES) III creatinine values. ${ }^{6}$ eGFR, an estimate of kidney function, was calculated using 98 the CKD Epidemiology Collaboration (CKD-EPI) creatinine equation. ${ }^{5}$ The annual change in

99 eGFR ( $\triangle \mathrm{eGFR})$ was calculated for each participant as the follow-up minus baseline eGFR value

100 divided by the number of years between the two visits.

101 This study primarily focused on the continuous eGFR and $\triangle \mathrm{eGFR}$ measures of kidney

102 function, with a secondary emphasis on dichotomous traits of CKD and rapid decline in eGFR.

103 Participants were categorized as having CKD stage $\geq 3$ at the baseline visit if they had eGFR

104 values $<60 \mathrm{~mL} / \mathrm{min} / 1.73 \mathrm{~m}^{2}$. New-onset CKD stage $\geq 3$ was defined as a follow-up eGFR $<60$

$105 \mathrm{~mL} / \mathrm{min} / 1.73 \mathrm{~m}^{2}$ in participants who had eGFR values $\geq 60 \mathrm{~mL} / \mathrm{min} / 1.73 \mathrm{~m}^{2}$ at baseline and a

106 concomitant $\geq 30 \%$ reduction in eGFR between baseline and follow-up. ${ }^{22}$ Rapid decline in eGFR

107 was defined as a decline in eGFR of at least $3 \mathrm{~mL} / \mathrm{min} / 1.73 \mathrm{~m}^{2}$ per year between baseline and 108 follow-up.

109 Meta-analyzed GWAS of kidney function traits

110 Publicly available kidney trait GWAS summary statistics were obtained from the

111 CKDGen Consortium website (https://ckdgen.imbi.uni-freiburg.de/) as reported in a 2019 meta-

112 analysis that identified genetic variants associated with eGFR and CKD (eGFR $<60$

$113 \mathrm{~mL} / \mathrm{min} / 1.73 \mathrm{~m}^{2}$ ) in trans-ethnic and European Ancestry populations. ${ }^{17}$

114 Association of protein biomarkers with kidney traits

115 The primary kidney function outcomes were cross-sectional eGFR at the baseline visit,

116 and longitudinal $\triangle \mathrm{eGFR}$ (i.e., eGFR at follow-up minus eGFR at baseline). The statistical

117 associations of each protein biomarker with these traits were evaluated using linear mixed

118 models. 
medRxiv preprint doi: https://doi.org/10.1101/2022.01.04.22268737; this version posted January 5, 2022. The copyright holder for this preprint

(which was not certified by peer review) is the author/funder, who has granted medRxiv a license to display the preprint in perpetuity.

This article is a US Government work. It is not subject to copyright under 17 USC 105 and is also made available

CVD biomarkers and kidney function

120 baseline visit, new-onset CKD at follow-up, and longitudinal rapid decline in eGFR. The

121 statistical associations between variation in the protein distribution and these dichotomous

122 kidney function traits were evaluated using logistic regression models.

All multivariable models were adjusted for the following kidney dysfunction risk factors

124 at baseline: age, sex, BMI, systolic blood pressure, total and HDL cholesterol, blood pressure

125 and/or lipid medication use, prevalent CVD, DM, and cigarette smoking status (current smokers

126 vs. non-smokers). Longitudinal analyses (i.e., models evaluating $\triangle \mathrm{eGFR}$, new-onset CKD, and

127 rapid decline in eGFR) were additionally adjusted for baseline eGFR, and only those participants

128 with available longitudinal data and who had a baseline eGFR $\geq 60 \mathrm{~mL} / \mathrm{min} / 1.73 \mathrm{~m}^{2}$ were

129 included in the model assessing new-onset CKD $(\mathrm{n}=2,257)$. We defined a "clinical model"

130 including all covariates except the protein biomarker of interest (i.e., reduced model), and a "full

131 model" including all covariates in the clinical model and the protein biomarker of interest.

132 For each protein biomarker, we evaluated the quantitative contribution of the protein

133 biomarker to variation in continuous kidney trait outcomes by comparing the goodness-of-fit $\mathrm{R}^{2}$

134 value of the main and full models. The change in $\mathrm{R}^{2}\left(\Delta \mathrm{R}^{2}\right)$ illustrates the incremental impact of

135 the addition of the protein biomarker over and above the clinical model. For the dichotomous

136 kidney function traits, we compared receiver operating characteristic (ROC) curves between the

137 clinical and full models using a contrast matrix to quantify the difference in the area under the

138 empirical ROC curve (i.e., the c-statistic). Results of the ROC curve comparison fit a chi-square

139 distribution, which was used to evaluate statistical significance. We calculated the false

140 discovery rate (FDR) for all associations, and FDR values $<0.05$ were interpreted as statistically 
medRxiv preprint doi: https://doi.org/10.1101/2022.01.04.22268737; this version posted January 5, 2022. The copyright holder for this preprint

(which was not certified by peer review) is the author/funder, who has granted medRxiv a license to display the preprint in perpetuity.

This article is a US Government work. It is not subject to copyright under 17 USC 105 and is also made available

CVD biomarkers and kidney function

141 significant. Discovery protein-trait statistical analyses were performed in SAS version 9.4 (SAS

142 Institute, Cary, NC).

$143 \quad$ Validation of continuous kidney function outcomes

144 We conducted internal validation of the protein biomarkers significantly associated with

145 eGFR in cross-sectional discovery analysis and with $\triangle \mathrm{eGFR}$ in longitudinal discovery analyses.

146 Protein biomarkers that were significantly associated with eGFR in the FHS Offspring cohort

147 were subsequently validated in 3,951 participants in the FHS Third Generation cohort ${ }^{23}$ using

148 data from the first (2002-2005) and second (2009-2011) exams of this cohort. Third Generation

149 cohort participants were included in the internal validation sample if they had serum creatinine

150 and the SABRe plasma protein measurements and did not have a medical record-confirmed

151 diagnosis of heart failure or myocardial infarction. Statistical significance of the internal

152 validation analyses was defined as a Bonferroni-corrected p-value of $0.05 /$ total number of

153 proteins included in the validation analysis. Validation analyses were performed in SAS version

1549.4 (SAS Institute, Cary, NC).

155 Two-sample Mendelian randomization (MR)

156 We used a two-sample MR approach ${ }^{24}$ to test the hypothesis that protein concentrations

157 associated with eGFR in the discovery and validation protein-trait analyses are causally related

158 to continuous eGFR using data from published kidney trait GWAS. ${ }^{17}$ Prior genome-wide

159 association studies (GWAS) of SABRe proteins in FHS participants identified protein

160 quantitative trait loci (pQTL) variants for 57 of the 71 protein biomarkers. ${ }^{25}$ Of these previously

161 identified variants, we considered only cis-pQTL variants for protein biomarkers that were

162 significantly associated with cross-sectional eGFR or longitudinal $\triangle \mathrm{eGFR}$ in the validation

163 analysis in the Third Generation cohort. cis-pQTL variants were defined as those single 
medRxiv preprint doi: https://doi.org/10.1101/2022.01.04.22268737; this version posted January 5, 2022. The copyright holder for this preprint

(which was not certified by peer review) is the author/funder, who has granted medRxiv a license to display the preprint in perpetuity.

This article is a US Government work. It is not subject to copyright under 17 USC 105 and is also made available

CVD biomarkers and kidney function

164 nucleotide polymorphisms (SNPs) that were located 1 megabase upstream or downstream of the

165 protein-coding gene's transcription start site. Furthermore, $c i s$-pQTL variants were pruned at

166 linkage disequilibrium $\mathrm{r}^{2}<0.01$, and only those that overlapped with SNPs from the kidney

167 function GWAS were used as instrumental variables for the protein biomarkers.

168 For protein biomarkers with only one pQTL variant as an instrumental variant in MR

169 analysis after pruning, the causal effect was calculated using the Wald test. For protein

170 biomarkers with more than one pQTL variant after pruning, the causal effect was calculated

171 using inverse-variance weighted meta-analyzed estimates. MR results were interpreted as

172 statistically significant after applying a Bonferroni correction for the total number of unique

173 protein biomarkers tested across all outcomes (i.e., $\mathrm{p}<0.05 / \mathrm{n}$, where $\mathrm{n}$ is the number of protein-

174 trait associations tested).

175 In the case of multiple cis-pQTL variants contributing to a significant weighted causal

176 estimate, we conducted sensitivity analyses for heterogeneity. When more than two pQTL

177 variants or SNPs contributed to a significant weighted causal estimate, we additionally tested for

178 horizontal pleiotropy and evaluated the change in the effect estimate after excluding one variant

179 at a time from the calculation (i.e., leave-one-out analysis).

180 All MR analyses were conducted in $\mathrm{R}$ version 4.0.2 using the TwoSampleMR

181 package. $^{24,26}$

182 Results

183 Participant characteristics

184 Baseline characteristics of participants in the FHS Offspring and Third Generation cross-

185 sectional cohorts are presented in Table 1. The mean age of participants in the Offspring cohort

186 was $60 \pm 9$ years and mean eGFR was $84 \pm 16 \mathrm{~mL} / \mathrm{min} / 1.73 \mathrm{~m}^{2}$. Seven percent of the Offspring 
medRxiv preprint doi: https://doi.org/10.1101/2022.01.04.22268737; this version posted January 5, 2022. The copyright holder for this preprint

(which was not certified by peer review) is the author/funder, who has granted medRxiv a license to display the preprint in perpetuity.

This article is a US Government work. It is not subject to copyright under 17 USC 105 and is also made available for use under a CCO license.

CVD biomarkers and kidney function

187 cohort had CKD at baseline, while the prevalence of DM and hypertension were $10 \%$ and $43 \%$,

188 respectively. The mean age of participants in the Third Generation cohort was $40 \pm 9$ years and

189 mean eGFR was $102 \pm 14 \mathrm{~mL} / \mathrm{min} / 1.73 \mathrm{~m}^{2}$. Less than one percent of the Third Generation cohort

190 sample had CKD, while the prevalence of DM and hypertension were 3\% and 18\%, respectively.

191 Follow-up characteristics of FHS Offspring (discovery) cohort participants included in

192 longitudinal analysis of $\triangle \mathrm{eGFR}$, new-onset CKD, and rapid decline in eGFR are presented in

193 Supplemental Table 2. The mean age of Offspring cohort participants at follow-up was $66 \pm 9$

194 years and mean annual $\triangle \mathrm{eGFR}$ between baseline and follow-up was $-0.97 \pm 1.73$

$195 \mathrm{~mL} / \mathrm{min} / 1.73 \mathrm{~m}^{2}$. Among participants who did not have CKD at baseline, $3 \%$ experienced new-

196 onset CKD during follow-up while $91 \%$ maintained their eGFR at over $60 \mathrm{~mL} / \mathrm{min} / 1.73 \mathrm{~m}^{2}$. The

197 remaining participants had a follow-up eGFR $<60 \mathrm{~mL} / \mathrm{min} / 1.73 \mathrm{~m}^{2}$, but had a reduction in eGFR

$198<30 \%$. Eleven percent of the Offspring cohort sample included in longitudinal analysis

199 experienced rapid decline in eGFR between baseline and follow-up.

200 Discovery and validation of cross-sectional and longitudinal protein-eGFR associations

201 Cross-sectional associations of each of the 71 protein biomarkers with eGFR and the

202 incremental increase in model $\mathrm{R}^{2}$ associated with each protein biomarker are presented in

203 Supplemental Table 3. Thirty-seven protein biomarkers were significantly associated with

204 eGFR (at FDR <0.05) in cross-sectional analysis, and of these, all but one (butyrylcholine

205 esterase) had an inverse association with eGFR. Six protein biomarkers were significantly

206 associated with a change in $\mathrm{R}^{2} \geq 5 \%$, including alpha-1-microglobulin (A1M), adipsin, beta-2-

207 microglobulin (B2M), cystatin C, myoglobin, and resistin. Of the 37 protein biomarkers that

208 were significantly associated with eGFR in the Offspring cohort in cross-sectional analysis, 20 
medRxiv preprint doi: https://doi.org/10.1101/2022.01.04.22268737; this version posted January 5, 2022. The copyright holder for this preprint

(which was not certified by peer review) is the author/funder, who has granted medRxiv a license to display the preprint in perpetuity.

This article is a US Government work. It is not subject to copyright under 17 USC 105 and is also made available for use under a CCO license.

CVD biomarkers and kidney function

were also significantly associated with eGFR in the Third Generation cohort at

$210 \mathrm{p}=0.05 / 37=0.00135$ (Supplemental Table 4).

Longitudinal associations of each of the 71 protein biomarkers with $\triangle \mathrm{eGFR}$ and the

212 incremental increase in model $\mathrm{R}^{2}$ associated with each protein biomarker are presented in

213 Supplemental Table 5. Twenty-seven protein biomarkers were significantly associated with

$214 \triangle \mathrm{eGFR}$ at FDR $<0.05$. All significant protein biomarkers except two (plasminogen activator

215 inhibitor 1 [PAI1] and dipeptidyl dipeptidase [DPP4]) were inversely associated with $\triangle \mathrm{eGFR}$.

$216 \mathrm{~B} 2 \mathrm{M}$ and cystatin $\mathrm{C}$ were associated with the largest increases in $\mathrm{R}^{2}\left(\Delta \mathrm{R}^{2}=3.3 \%\right.$ and $2.5 \%$,

217 respectively). Of the 27 proteins that were significantly associated with $\triangle \mathrm{eGFR}$ in the Offspring

218 cohort in longitudinal analysis, 12 were also significantly associated with $\triangle \mathrm{eGFR}$ in the Third

219 Generation cohort at $\mathrm{p}=0.05 / 27=0.00185$ (Supplemental Table 6).

220 Discovery protein-trait associations: Cross-sectional associations with secondary outcomes in the

221 Offspring cohort

222 Cross-sectional associations of each of the 71 protein biomarkers with prevalent CKD

223 and the associated change in the C-statistic are presented in Supplemental Table 7. Thirty-five

224 protein biomarkers were significantly associated with prevalent CKD at FDR $<0.05$, and of these,

225 all but one (angiopoietin-like 3) were associated with greater log-odds of CKD. Ten protein

226 biomarkers were associated with a statistically significant change in the C-statistic.

227 Discovery protein-trait associations: Longitudinal associations with secondary outcomes in the

228 Offspring cohort

229 Five protein biomarkers were significantly associated with higher log-odds of new-onset

230 CKD at FDR<0.05 (Supplemental Table 8), while 17 protein biomarkers were significantly

231 associated with higher log-odds of rapid decline in eGFR (Supplemental Table 9). No 
medRxiv preprint doi: https://doi.org/10.1101/2022.01.04.22268737; this version posted January 5, 2022. The copyright holder for this preprint (which was not certified by peer review) is the author/funder, who has granted medRxiv a license to display the preprint in perpetuity. This article is a US Government work. It is not subject to copyright under 17 USC 105 and is also made available

CVD biomarkers and kidney function

232 biomarkers were associated with a significant increase in the model C-statistic for either rapid

233 decline in eGFR or new-onset CKD.

234 Causal inference

235 Twenty-four unique proteins were significantly associated with eGFR in both the

236 Offspring and Third Generation in cross-sectional and/or longitudinal analyses; therefore,

237 statistical significance for all MR analyses was set at a Bonferroni-corrected p-value of 0.05/24=

238 0.00208. The 24 protein biomarkers associated with eGFR had a total of 25 cis-pQTL variants

239 that overlapped with SNPs in the eGFR GWAS ${ }^{17}$ and were included in MR analyses. Significant

240 results of MR analysis (protein $\rightarrow$ kidney trait) for proteins that were significantly associated

241 with eGFR or with $\triangle \mathrm{eGFR}$ are presented in Table 3; full MR results for all protein biomarkers

242 with cis-pQTL variants are presented in Supplemental Table 10. Higher concentrations of

243 epidermal growth factor-containing fibulin-like extracellular matrix protein 1 (EFEMP1) and

244 melanoma cell adhesion molecule (MCAM) were significantly associated with lower eGFR $(\beta \pm$

245 SE $-0.0064 \pm 0.0016$ and $-0.0111 \pm 0.0027$, respectively), consistent with a potentially causal

246 relationship. Sensitivity analysis of the two EFEMP1 pQTL variants indicated no heterogeneity

$247(\mathrm{p}=0.69$, Supplemental Table 9).

\section{Discussion/Conclusion}

249 We identified a total of 43 CVD-related protein biomarkers associated with eGFR, a

250 continuous measure of kidney function, in cross-sectional and/or longitudinal discovery analysis.

251 Among these, eight proteins were significantly associated with both eGFR and $\triangle \mathrm{eGFR}$ in the

252 FHS Offspring discovery sample and the FHS Third Generation validation sample. Of the 37

253 proteins associated with eGFR and 27 proteins associated with $\triangle$ eGFR in the FHS Offspring

254 cohort (i.e. discovery), 20 and 12 were associated with the corresponding trait in the FHS Third 
medRxiv preprint doi: https://doi.org/10.1101/2022.01.04.22268737; this version posted January 5, 2022. The copyright holder for this preprint

(which was not certified by peer review) is the author/funder, who has granted medRxiv a license to display the preprint in perpetuity.

This article is a US Government work. It is not subject to copyright under 17 USC 105 and is also made available

CVD biomarkers and kidney function

255 Generation cohort (i.e. validation). This group of protein biomarkers included EFEMP1 and

256 MCAM, which were putatively causally related to eGFR in MR analysis. To our knowledge,

257 causal relations of protein biomarkers to CKD based on an integrative genomic approach have

258 not been reported previously.

259

CKD and CVD share several risk factors; identifying early mechanisms linking the two

260 disease processes may provide insights into targeted interventions to prevent or delay the onset

261 of clinically overt disease. The most notable shared risk factors are DM and hypertension. DM is

262 associated with systemic inflammation and oxidative stress, ${ }^{27}$ which in turn are associated with

263 microvascular and macrovascular complications and kidney damage. ${ }^{28,29}$ Hypertension results in

264 prolonged exposure of the heart, kidney, and vasculature to elevated hemodynamic load that can

265 contribute to left ventricular hypertrophy, vascular stiffening, heart failure, and CKD. ${ }^{30}$ Over-

266 activation of the renin-angiotensin-aldosterone system, which increases blood pressure through

267 multiple mechanisms, can damage glomerular cells. ${ }^{13}$ Treatment of hypertension can prevent

268 CKD progression, ${ }^{31}$ while conversely, kidney disease can lead to resistant hypertension. ${ }^{32}$

269 Furthermore, inflammation also contributes to development of both CKD and CVD. In CKD, the

270 concentration of inflammatory proteins is inversely related to eGFR, and the cytokine interleukin

271 (IL)-6 is a reliable predictor of adverse clinical outcomes in individuals with CKD. ${ }^{14,33,34}$ Chronic

272 inflammation also may cause oxidative stress and endothelial dysfunction, which contribute to

273 microvascular damage, new-onset or worsening CKD, and clinical CVD. ${ }^{15}$

274 The eGFR values observed in the FHS Offspring participants included in the discovery

275 stage of this study were mostly in the normal range and few individuals experience a rapid

276 decline in eGFR $(n=265 ; 11 \%)$ or progressed to new-onset CKD ( $\mathrm{n}=72 ; 3 \%)$ during follow-up.

277 Under normal conditions, the glomerulus is able to freely filter proteins with molecular weight 
medRxiv preprint doi: https://doi.org/10.1101/2022.01.04.22268737; this version posted January 5, 2022. The copyright holder for this preprint

(which was not certified by peer review) is the author/funder, who has granted medRxiv a license to display the preprint in perpetuity.

This article is a US Government work. It is not subject to copyright under 17 USC 105 and is also made available for use under a CCO license.

CVD biomarkers and kidney function

$(\mathrm{MW})<70$ kilodaltons $(\mathrm{kDa})$, and as such, many of the proteins identified in the cross-sectional and longitudinal protein-trait analyses may reflect early impaired kidney clearance of proteins with low molecular weights with a resultant increase in concentrations of circulating proteins. ${ }^{35}$

281 Indeed, the vast majority of protein biomarkers showed negative associations with eGFR (i.e.,

282 lower eGFR was associated with higher protein levels), thus many of the protein biomarkers

283 identified in this study are likely downstream biomarkers of reduced kidney function.

284 Accordingly, the protein biomarkers with consistent and highly significant associations are well-

285 established markers of kidney function, and our validation in the Third Generation cohort of

286 many of the discovery associations observed in the Offspring cohort emphasize associations of

287 these proteins with kidney function in a younger, healthier population with little prevalent CKD.

288 Eight protein biomarkers were associated with both eGFR and $\triangle \mathrm{eGFR}$ in both the Offspring and

289 Third Generation cohorts, including adipsin, adrenomedullin (ADM), A1M, B2M, collagen type

290 XVIII alpha 1 (COL18A1), cystatin C, EFEMP1, and fibroblast growth factor 23 (FGF23). Of

291 these, cystatin C (MW $15.8 \mathrm{kDa})$ and B2M (MW $13.7 \mathrm{kDa})$ were associated with all kidney traits

292 and are used in alternative eGFR calculations due to their low MW and their role as early

293 indicators of kidney impairment, and they are additionally associated with CVD outcomes. ${ }^{16,36-39}$

294 Other protein biomarkers significantly associated with eGFR and $\triangle \mathrm{eGFR}$ are also associated

295 with inflammation and kidney disease and may represent non-traditional markers of kidney

296 function due to parallel mechanisms relevant also to CVD. A1M (MW 29.8 kDa), while having a

297 slightly higher MW than either cystatin C or B2M, has also been proposed as a biomarker of

298 kidney disease progression. ${ }^{40-42}$ Similarly, adipsin (MW 27.0 kDa), ADM (MW 20.4 kDa),

299 FGF23 (MW 28.0 kDa), and endostatin, a $20 \mathrm{kDa}$ fragment of the 178.2 kDa COL18A1, were all

300 reported to be elevated in the setting of kidney disease in prior studies. ${ }^{43-47}$ These protein 
medRxiv preprint doi: https://doi.org/10.1101/2022.01.04.22268737; this version posted January 5, 2022. The copyright holder for this preprint

(which was not certified by peer review) is the author/funder, who has granted medRxiv a license to display the preprint in perpetuity.

This article is a US Government work. It is not subject to copyright under 17 USC 105 and is also made available

CVD biomarkers and kidney function

301 biomarkers showed a robust association with kidney traits and it is possible that they reflect

302 CKD risk early in the subclinical disease process.

We hypothesized a priori that a subset of proteins associated with kidney function may

304 be causal contributors to renal impairment. A recent MR analysis suggested a putatively causal

305 role of melanoma-derived growth regulatory protein (MIA), cystatin M, and carbonic anhydrase

306 III in kidney disease. ${ }^{55}$ While these proteins were not included in our assay, our MR analysis

307 evaluated 24 new protein biomarkers and revealed putatively causal inverse relations of

308 EFEMP1 and MCAM with eGFR. EFEMP1 is an extracellular matrix protein involved in both

309 cellular structure and signaling, and it was associated with worse eGFR cross-sectionally and

310 with $\triangle \mathrm{eGFR}$ longitudinally, with prevalent CKD, and with rapid decline in eGFR. A prior study

311 reported elevated EFEMP1 concentration in human kidney tissue with immunoglobulin A (IgA)

312 nephropathy. ${ }^{56}$ The causal mechanism is still unclear, but animal models suggest that EFEMP1

313 may be associated with vascular remodeling in hypertension. ${ }^{57}$ MCAM, also known as MUC18

314 or CD146, is expressed in endothelial cells and is significantly elevated in individuals with

315 diabetic nephropathy ${ }^{58,59}$ and CKD. ${ }^{60,61}$ Results of our protein-trait analysis similarly showed an

316 association between MCAM with both eGFR and CKD in cross-sectional analyses.

317 This study has several limitations that must be noted. The primary limitation is that a

318 custom assay used to measure the protein biomarkers in this study, which limited external

319 replication of our results. To address this limitation, we performed validation of the discovery

320 results from the FHS Offspring cohort in participants from the younger and healthier Third

321 Generation cohort in whom CKD was rare (0.3\% prevalent CKD at baseline). Independent

322 external replication of the protein biomarkers identified in this study is needed. 
medRxiv preprint doi: https://doi.org/10.1101/2022.01.04.22268737; this version posted January 5, 2022. The copyright holder for this preprint

(which was not certified by peer review) is the author/funder, who has granted medRxiv a license to display the preprint in perpetuity.

This article is a US Government work. It is not subject to copyright under 17 USC 105 and is also made available

CVD biomarkers and kidney function

In addition, we estimated kidney function based on a single creatinine measurement at

324 both baseline and follow-up, rather than using multiple eGFR values at each time point. As such,

325 our definition of CKD stage $\geq 3$ does not mirror the recommended clinical diagnosis of CKD,

326 which requires the presence of kidney structural or functional abnormalities for at least three

327 months. ${ }^{62}$ Furthermore, the younger and healthier cohort used for validation analyses limited our

328 ability to identify protein biomarkers of changing kidney function and CKD in longitudinal

329 analysis. Albuminuria and blood urea nitrogen may be clinically useful in the evaluation of

330 patients with impaired kidney function, but these data were not available for analysis in this

331 study. Our study population was limited to adults of European ancestry, which may limit

332 generalizability to other ancestry groups. Functional studies of the proteins reported to have

333 putatively causal relations to kidney function in this investigation may be warranted.

334 The primary strengths of this study are the large sample size and the integrative genomic

335 approach we employed. We reported cross-sectional and longitudinal protein-trait association

336 results to identify numerous proteins associated with kidney function and its change over time.

337 By integrating pQTL data for the proteins we measured with genetic variants from large GWAS

338 of kidney disease traits we identified putatively causal proteins for kidney function that represent

339 promising candidates for further studies with the ultimate goal to better treat or prevent CKD.

340 The results of the comprehensive cross-sectional and longitudinal analyses in this study

341 validate proteins that may detect of impaired kidney function early in the disease process when

342 treatment is most likely to be beneficial. We identified robust, significant associations between

34320 protein biomarkers with eGFR in cross-sectional discovery and validation analyses and 12

344 proteins with $\triangle \mathrm{eGFR}$ in longitudinal analyses both in discovery and validation. Additionally, two

345 proteins were found to be putatively causal for reduced kidney function in causal inference 
medRxiv preprint doi: https://doi.org/10.1101/2022.01.04.22268737; this version posted January 5, 2022. The copyright holder for this preprint (which was not certified by peer review) is the author/funder, who has granted medRxiv a license to display the preprint in perpetuity.

This article is a US Government work. It is not subject to copyright under 17 USC 105 and is also made available

CVD biomarkers and kidney function

346 testing. Further studies are necessary to determine if any of the proteins identified by MR can

347 serve as useful biomarkers for CKD either individually or in combination with known and

348 validated biomarkers.

349 
medRxiv preprint doi: https://doi.org/10.1101/2022.01.04.22268737; this version posted January 5, 2022. The copyright holder for this preprint

(which was not certified by peer review) is the author/funder, who has granted medRxiv a license to display the preprint in perpetuity.

This article is a US Government work. It is not subject to copyright under 17 USC 105 and is also made available

CVD biomarkers and kidney function

\section{References}

351 1. Saran R, Robinson B, Abbott KC, et al. US Renal Data System 2017 Annual Data Report:

352 Epidemiology of Kidney Disease in the United States. Am J kidney Dis Off J Natl Kidney

$353 \quad$ Found. 2018;71(3 Suppl 1):A7. doi:10.1053/j.ajkd.2018.01.002

354 2. Joubert BR, Felix JF, Yousefi P, et al. DNA Methylation in Newborns and Maternal

355 Smoking in Pregnancy: Genome-wide Consortium Meta-analysis. Am J Hum Genet.

356 2016;98(4):680-696. doi:https://doi.org/10.1016/j.ajhg.2016.02.019

357 3. Bikbov B, Purcell CA, Levey AS, et al. Global, regional, and national burden of chronic

358 kidney disease, 1990\&\#x2013;2017: a systematic analysis for the Global Burden of

359 Disease Study 2017. Lancet. 2020;395(10225):709-733. doi:10.1016/S0140-

$360 \quad 6736(20) 30045-3$

361 4. Gansevoort RT, Matsushita K, van der Velde M, et al. Lower estimated GFR and higher

albuminuria are associated with adverse kidney outcomes. A collaborative meta-analysis

364 of general and high-risk population cohorts. Kidney Int. 2011;80(1):93-104.

365 5. Levey AS, Stevens LA, Schmid CH, et al. A new equation to estimate glomerular filtration rate. Ann Intern Med. 2009;150(9):604-612. doi:10.7326/0003-4819-150-9-

200905050-00006

368 6. Fox CS, Larson MG, Leip EP, Culleton B, Wilson PWF, Levy D. Predictors of New-

369 Onset Kidney Disease in a Community-Based Population. JAMA. 2004;291(7):844-850.

$370 \quad$ doi:10.1001/jama.291.7.844

371 7. Flint AC, Conell C, Ren X, et al. Effect of Systolic and Diastolic Blood Pressure on

372 Cardiovascular Outcomes. N Engl J Med. 2019;381(3):243-251. 
medRxiv preprint doi: https://doi.org/10.1101/2022.01.04.22268737; this version posted January 5, 2022. The copyright holder for this preprint

(which was not certified by peer review) is the author/funder, who has granted medRxiv a license to display the preprint in perpetuity.

This article is a US Government work. It is not subject to copyright under 17 USC 105 and is also made available for use under a CCO license.

CVD biomarkers and kidney function

374 8. Dokken BB. The Pathophysiology of Cardiovascular Disease and Diabetes: Beyond Blood Pressure and Lipids. Diabetes Spectr. 2008;21(3):160 LP - 165. doi:10.2337/diaspect.21.3.160

377 9. Zelnick LR, Weiss NS, Kestenbaum BR, et al. Diabetes and CKD in the United States

Population, 2009-2014. Clin J Am Soc Nephrol. 2017;12(12):1984 LP - 1990. doi:10.2215/CJN.03700417

10. United States Renal Data System. 2020 USRDS Annual Data Report: Epidemiology of Kidney Disease in the United States.; 2020.

11. Kibria GM Al, Crispen R. Prevalence and trends of chronic kidney disease and its risk

12. Centers for Disease Control and Prevention. Chronic Kidney Disease Surveillance System-United States. Published 2020. http://www.cdc.gov/ckd

13. Gajjala PR, Sanati M, Jankowski J. Cellular and Molecular Mechanisms of Chronic

Kidney Disease with Diabetes Mellitus and Cardiovascular Diseases as Its Comorbidities.

390 14. Cachofeiro V, Goicochea M, de Vinuesa SG, Oubiña P, Lahera V, Luño J. Oxidative stress and inflammation, a link between chronic kidney disease and cardiovascular disease: New strategies to prevent cardiovascular risk in chronic kidney disease. Kidney

394 15. Podkowińska A, Formanowicz D. Chronic Kidney Disease as Oxidative Stress- and Inflammatory-Mediated Cardiovascular Disease. Antioxidants (Basel, Switzerland). 
medRxiv preprint doi: https://doi.org/10.1101/2022.01.04.22268737; this version posted January 5, 2022. The copyright holder for this preprint

(which was not certified by peer review) is the author/funder, who has granted medRxiv a license to display the preprint in perpetuity.

This article is a US Government work. It is not subject to copyright under 17 USC 105 and is also made available for use under a CCO license.

CVD biomarkers and kidney function

16. Ho JE, Lyass A, Courchesne P, et al. Protein Biomarkers of Cardiovascular Disease and Mortality in the Community. J Am Heart Assoc. 2018;7(14):e008108. doi:10.1161/JAHA.117.008108

17. Wuttke M, Li Y, Li M, et al. A catalog of genetic loci associated with kidney function from analyses of a million individuals. Nat Genet. 2019;51(6):957-972. doi:10.1038/s41588-019-0407-X

18. Kannel WB, Feinleib M, McNamara PM, Garrison RJ, Castelli WP. An investigation of coronary heart disease in families: the Framinham Offspring Study. Am J Epidemiol.

19. Tsao CW, Vasan RS. Cohort Profile: The Framingham Heart Study (FHS): overview of milestones in cardiovascular epidemiology. Int J Epidemiol. 2015;44(6):1800-1813.

20. Association AD. 2. Classification and Diagnosis of Diabetes: \&lt;em\&gt;Standards of Medical Care in Diabetes-2020\&1t;/em\&gt; Diabetes Care. 2020;43(Supplement 1):S14 LP-S31. doi:10.2337/dc20-S002

412 21. Chobanian A V, Bakris GL, Black HR, et al. Seventh Report of the Joint National 413 Committee on Prevention, Detection, Evaluation, and Treatment of High Blood Pressure. Hypertension. 2003;42(6):1206-1252. doi:10.1161/01.HYP.0000107251.49515.c2

415 22. Levey AS, Inker LA, Matsushita K, et al. GFR decline as an end point for clinical trials in 416 CKD: a scientific workshop sponsored by the National Kidney Foundation and the US 417 Food and Drug Administration. Am J kidney Dis Off J Natl Kidney Found. 418 2014;64(6):821-835. doi:10.1053/j.ajkd.2014.07.030 
medRxiv preprint doi: https://doi.org/10.1101/2022.01.04.22268737; this version posted January 5, 2022. The copyright holder for this preprint

(which was not certified by peer review) is the author/funder, who has granted medRxiv a license to display the preprint in perpetuity.

This article is a US Government work. It is not subject to copyright under 17 USC 105 and is also made available

CVD biomarkers and kidney function

23. Splansky GL, Corey D, Yang Q, et al. The Third Generation Cohort of the National Heart, Lung, and Blood Institute's Framingham Heart Study: Design, Recruitment, and Initial Examination. Am J Epidemiol. 2007;165(11):1328-1335. doi:10.1093/aje/kwm021

24. Hemani G, Zheng J, Elsworth B, et al. The MR-Base platform supports systematic causal inference across the human phenome. Elife. 2018;7. doi:10.7554/eLife.34408

25. Yao C, Chen G, Song C, et al. Genome $\square$ wide mapping of plasma protein QTLs identifies putatively causal genes and pathways for cardiovascular disease. Nat Commun. 2018;9(1):3268. doi:10.1038/s41467-018-05512-x

427 26. Hemani G, Tilling K, Davey Smith G. Orienting the causal relationship between

27. Odegaard AO, Jacobs DRJ, Sanchez OA, Goff DCJ, Reiner AP, Gross MD. Oxidative stress, inflammation, endothelial dysfunction and incidence of type 2 diabetes.

433 28. Lv W, Booz GW, Wang Y, Fan F, Roman RJ. Inflammation and renal fibrosis: Recent developments on key signaling molecules as potential therapeutic targets. Eur J

29. Jha JC, Ho F, Dan C, Jandeleit-Dahm K. A causal link between oxidative stress and inflammation in cardiovascular and renal complications of diabetes. Clin Sci (Lond). 2018;132(16):1811-1836. doi:10.1042/CS20171459

439 30. Nwabuo CC, Appiah D, Moreira HT, et al. Long-term cumulative blood pressure in young adults and incident heart failure, coronary heart disease, stroke, and cardiovascular disease: The CARDIA study. Eur J Prev Cardiol. Published online April 
medRxiv preprint doi: https://doi.org/10.1101/2022.01.04.22268737; this version posted January 5, 2022. The copyright holder for this preprint

(which was not certified by peer review) is the author/funder, who has granted medRxiv a license to display the preprint in perpetuity.

This article is a US Government work. It is not subject to copyright under 17 USC 105 and is also made available for use under a CCO license.

CVD biomarkers and kidney function

443 31. Ptinopoulou AG, Pikilidou MI, Lasaridis AN. The effect of antihypertensive drugs on chronic kidney disease: a comprehensive review. Hypertens Res. 2013;36(2):91-101.

32. Carey RM, Calhoun DA, Bakris GL, et al. Resistant Hypertension: Detection, Evaluation, and Management: A Scientific Statement From the American Heart Association. Hypertens (Dallas, Tex 1979). 2018;72(5):e53-e90.

33. Sun J, Axelsson J, Machowska A, et al. Biomarkers of Cardiovascular Disease and

453 34. Gupta J, Mitra N, Kanetsky PA, et al. Association between albuminuria, kidney function, and inflammatory biomarker profile in CKD in CRIC. Clin J Am Soc Nephrol. 2012;7(12):1938-1946. doi:10.2215/CJN.03500412

35. Strober W, Waldmann TA. The role of the kidney in the metabolism of plasma proteins.

458 36. Argyropoulos CP, Chen SS, Ng Y-H, et al. Rediscovering Beta-2 Microglobulin As a

459 Biomarker across the Spectrum of Kidney Diseases. Front Med. 2017;4:73. doi:10.3389/fmed.2017.00073

461 37. Joseph Y, N. BE, C. MA, et al. Impact of Kidney Function on the Blood Proteome and on 462 Protein Cardiovascular Risk Biomarkers in Patients With Stable Coronary Heart Disease. J Am Heart Assoc. 2020;9(15):e016463. doi:10.1161/JAHA.120.016463

464 38. Liu X, Foster MC, Tighiouart H, et al. Non-GFR Determinants of Low-Molecular-Weight 
medRxiv preprint doi: https://doi.org/10.1101/2022.01.04.22268737; this version posted January 5, 2022. The copyright holder for this preprint

(which was not certified by peer review) is the author/funder, who has granted medRxiv a license to display the preprint in perpetuity.

This article is a US Government work. It is not subject to copyright under 17 USC 105 and is also made available for use under a CCO license.

CVD biomarkers and kidney function

465

466

467

468

469

470

471

472

473

474

475

476

477

478

479

480

481

482

483

484

485

486

487

Serum Protein Filtration Markers in CKD. Am J kidney Dis Off J Natl Kidney Found. 2016;68(6):892-900. doi:10.1053/j.ajkd.2016.07.021

39. Christensson A, Ash JA, DeLisle RK, et al. The Impact of the Glomerular Filtration Rate on the Human Plasma Proteome. PROTEOMICS - Clin Appl. 2018;12(3):1700067. doi:https://doi.org/10.1002/prca.201700067

40. Luczak M, Formanowicz D, Pawliczak E, Wanic-Kossowska M, Wykretowicz A, Figlerowicz M. Chronic kidney disease-related atherosclerosis - proteomic studies of blood plasma. Proteome Sci. 2011;9:25. doi:10.1186/1477-5956-9-25

41. Jotwani V, Katz R, Ix JH, et al. Urinary Biomarkers of Kidney Tubular Damage and Risk of Cardiovascular Disease and Mortality in Elders. Am J Kidney Dis. 2018;72(2):205-213. doi:10.1053/j.ajkd.2017.12.013

42. Vyssoulis GP, Tousoulis D, Antoniades C, Dimitrakopoulos S, Zervoudaki A, Stefanadis C. $\alpha-1$ Microglobulin as a New Inflammatory Marker in Newly Diagnosed Hypertensive Patients: . Am J Hypertens. 2007;20(9):1016-1021. doi:10.1016/j.amjhyper.2007.01.010

43. Volanakis JE, Barnum SR, Giddens M, Galla JH. Renal Filtration and Catabolism of Complement Protein D. N Engl J Med. 1985;312(7):395-399.

doi:10.1056/NEJM198502143120702

44. Velho G, Ragot S, Mohammedi K, et al. Plasma Adrenomedullin and Allelic Variation in the ADM Gene and Kidney Disease in People With Type 2 Diabetes. Diabetes. 2015;64(9):3262-3272. doi:10.2337/db14-1852

45. Fliser D, Kollerits B, Neyer U, et al. Fibroblast Growth Factor 23 (FGF23) Predicts Progression of Chronic Kidney Disease: The Mild to Moderate Kidney Disease (MMKD) Study. J Am Soc Nephrol. 2007;18(9):2600 LP - 2608. doi:10.1681/ASN.2006080936 
medRxiv preprint doi: https://doi.org/10.1101/2022.01.04.22268737; this version posted January 5, 2022. The copyright holder for this preprint

(which was not certified by peer review) is the author/funder, who has granted medRxiv a license to display the preprint in perpetuity.

This article is a US Government work. It is not subject to copyright under 17 USC 105 and is also made available

CVD biomarkers and kidney function

46. Dieplinger B, Mueller T, Kollerits B, et al. Pro-A-type natriuretic peptide and proadrenomedullin predict progression of chronic kidney disease: the MMKD Study. Kidney Int. 2009;75(4):408-414. doi:10.1038/ki.2008.560

491 47. Pena MJ, Heinzel A, Heinze G, et al. A panel of novel biomarkers representing different disease pathways improves prediction of renal function decline in type 2 diabetes. PLoS One. 2015;10(5):e0120995-e0120995. doi:10.1371/journal.pone.0120995

48. Lau ES, Paniagua SM, Zarbafian S, et al. Cardiovascular Biomarkers of Obesity and Overlap With Cardiometabolic Dysfunction. J Am Heart Assoc. 2021;10(14):e020215e020215. doi:10.1161/JAHA.120.020215

49. Lampón N, Hermida-Cadahia EF, Riveiro A, Tutor JC. Association between butyrylcholinesterase activity and low-grade systemic inflammation. Ann Hepatol. 2012;11(3):356-363.

50. Małgorzewicz S, Skrzypczak-Jankun E, Jankun J. Plasminogen activator inhibitor-1 in kidney pathology (Review). Int J Mol Med. 2013;31(3):503-510.

51. Eddy AA, Fogo AB. Plasminogen Activator Inhibitor-1 in Chronic Kidney Disease:

506 52. Kanasaki K. The role of renal dipeptidyl peptidase-4 in kidney disease: renal effects of dipeptidyl peptidase-4 inhibitors with a focus on linagliptin. Clin Sci (Lond). 2018;132(4):489-507. doi:10.1042/CS20180031 2041. doi:10.2741/3361 
medRxiv preprint doi: https://doi.org/10.1101/2022.01.04.22268737; this version posted January 5, 2022. The copyright holder for this preprint

(which was not certified by peer review) is the author/funder, who has granted medRxiv a license to display the preprint in perpetuity.

This article is a US Government work. It is not subject to copyright under 17 USC 105 and is also made available

CVD biomarkers and kidney function

511 54. Shi S, Koya D, Kanasaki K. Dipeptidyl peptidase-4 and kidney fibrosis in diabetes.

Fibrogenesis Tissue Repair. 2016;9(1):1. doi:10.1186/s13069-016-0038-0

513 55. Matías-García PR, Wilson R, Guo Q, et al. Plasma Proteomics of Renal Function: A

514 Transethnic Meta-Analysis and Mendelian Randomization Study. J Am Soc Nephrol. 2021;32(7):1747 LP - 1763. doi:10.1681/ASN.2020071070

516 56. Paunas FTI, Finne K, Leh S, et al. Characterization of glomerular extracellular matrix in IgA nephropathy by proteomic analysis of laser-captured microdissected glomeruli. BMC Nephrol. 2019;20(1):410. doi:10.1186/s12882-019-1598-1

519 57. Lin Z, Wang Z, Li G, Li B, Xie W, Xiang D. Fibulin-3 may improve vascular health through inhibition of MMP-2/9 and oxidative stress in spontaneously hypertensive rats. Mol Med Rep. 2016;13(5):3805-3812. doi:10.3892/mmr.2016.5036

58. Fan Y, Fei Y, Zheng L, et al. Expression of Endothelial Cell Injury Marker Cd146

59. Saito T, Saito O, Kawano T, et al. Elevation of serum adiponectin and CD146 levels in diabetic nephropathy. Diabetes Res Clin Pract. 2007;78(1):85-92.

60. Bardin N, Moal V, Anfosso F, et al. Soluble CD146, a novel endothelial marker, is increased in physiopathological settings linked to endothelial junctional alteration. Thromb Haemost. 2003;90(5):915-920. doi:10.1160/TH02-11-0285

531 61. Wang N, Fan Y, Ni P, et al. High glucose effect on the role of CD146 in human proximal tubular epithelial cells in vitro. J Nephrol. 2008;21(6):931-940.

533 62. Levin A, Stevens P, Bilous RW, et al. Kidney disease: Improving global outcomes 
medRxiv preprint doi: https://doi.org/10.1101/2022.01.04.22268737; this version posted January 5, 2022. The copyright holder for this preprint (which was not certified by peer review) is the author/funder, who has granted medRxiv a license to display the preprint in perpetuity. This article is a US Government work. It is not subject to copyright under 17 USC 105 and is also made available

CVD biomarkers and kidney function

(KDIGO) CKD work group. KDIGO 2012 clinical practice guideline for the evaluation and management of chronic kidney disease. Kidney Int Suppl. 2013;3:1-150. 
medRxiv preprint doi: https://doi.org/10.1101/2022.01.04.22268737; this version posted January 5, 2022. The copyright holder for this preprint

(which was not certified by peer review) is the author/funder, who has granted medRxiv a license to display the preprint in perpetuity.

This article is a US Government work. It is not subject to copyright under 17 USC 105 and is also made available for use under a CCO license.

CVD biomarkers and kidney function

\section{Statements}

540 Statement of ethics: The study protocol was reviewed and approved by the Boston University

541 Medical Center Institutional Review Board. All study participants provided their written

542 informed consent for their data and biological samples to be used.

543 Conflict of interest statement: The authors have no conflicts of interest to declare.

544 Funding sources: The Framingham Heart Study laboratory work for this project was funded by

545 National Institutes of Health contract N01-HC-25195. The analytical component of this project

546 was funded by the Division of Intramural Research, National Heart, Lung, and Blood Institute,

547 National Institutes of Health, Bethesda, MD (D. Levy, Principal Investigator). The work of A

548 Köttgen was funded by the Deutsche Forschungsgesellschaft (DFG, German Research

549 Foundation) - Project-ID 431984000 - SFB 1453.

550 Disclaimer: The views expressed in this manuscript are those of the authors and do not

551 necessarily represent the views of the National Heart, Lung, and Blood Institute; the National

552 Institutes of Health; or the U.S. Department of Health and Human Services.

553 Author contributions: A Keshawarz, GY Lee, S Hwang, Z Yu, and C Yao contributed to data

554 analysis. All authors contributed to data interpretation. GY Lee, S Hwang, A Köttgen, and D

555 Levy conceived the research study. A Keshawarz drafted the manuscript. GY Lee, S Hwang, C

556 Yao, A Köttgen, and D Levy provided critical revisions. All authors gave final approval for

557 publication and are the guarantors of this work.

558 Data availability statement: The data presented in these analyses can be accessed through the

559 National Center for Biotechnology Information Database of Genotypes and Phenotypes

560 (accession number, phs00007.v29.p10). 
medRxiv preprint doi: https://doi.org/10.1101/2022.01.04.22268737; this version posted January 5, 2022. The copyright holder for this preprint

(which was not certified by peer review) is the author/funder, who has granted medRxiv a license to display the preprint in perpetuity.

This article is a US Government work. It is not subject to copyright under 17 USC 105 and is also made available for use under a CCO license.

CVD biomarkers and kidney function

\section{Tables}

\section{Table 1. Baseline demographic and clinical participant characteristics.}

\begin{tabular}{|c|c|c|}
\hline Characteristic & $\begin{array}{c}\text { Offspring cohort } \\
(n=2,873)\end{array}$ & $\begin{array}{l}\text { Third Generation cohort } \\
(n=3,951)\end{array}$ \\
\hline Age, years & $60 \pm 9$ & $40 \pm 9$ \\
\hline Women, n (\%) & $1,573(55 \%)$ & $2,109(53 \%)$ \\
\hline $\mathrm{eGFR}, \mathrm{mL} / \mathrm{min} / 1.73 \mathrm{~m}^{2}$ & $84 \pm 16$ & $102 \pm 14$ \\
\hline $\mathrm{CKD}, \mathrm{n}(\%)$ & $210(7 \%)$ & $10(0.3 \%)$ \\
\hline BMI, $\mathrm{kg} / \mathrm{m}^{2}$ & $27.95 \pm 5.22$ & $26.87 \pm 5.55$ \\
\hline Fasting glucose, $\mathrm{mg} / \mathrm{dL}$ & $102.99 \pm 24.59$ & $95.02 \pm 17.9$ \\
\hline Systolic blood pressure, mmHg & $126.18 \pm 18.54$ & $116.69 \pm 14.02$ \\
\hline Diastolic blood pressure, $\mathrm{mmHg}$ & $74.15 \pm 9.7$ & $75.26 \pm 9.63$ \\
\hline Total cholesterol, mg/dL & $200.64 \pm 36.42$ & $188.81 \pm 35.46$ \\
\hline HDL cholesterol, mg/dL & $54.41 \pm 17.2$ & $54.41 \pm 16.16$ \\
\hline $\mathrm{DM}, \mathrm{n}(\%)$ & $280(10 \%)$ & $114(3 \%)$ \\
\hline Hypertension, n (\%) & $1242(43 \%)$ & $726(18 \%)$ \\
\hline Current cigarette smoker, n (\%) & $362(13 \%)$ & $605(15 \%)$ \\
\hline $\begin{array}{l}\text { Cholesterol-lowering medication } \\
\text { use, } \mathrm{n}(\%)\end{array}$ & $564(20 \%)$ & $341(9 \%)$ \\
\hline $\begin{array}{l}\text { Prevalent cardiovascular disease, } \mathrm{n} \\
(\%)\end{array}$ & $308(11 \%)$ & $38(1 \%)$ \\
\hline
\end{tabular}

564 Abbreviations: eGFR, estimated glomerular filtration rate; CKD, chronic kidney disease; BMI, body mass index;

565 HDL, high density lipoprotein; DM, diabetes mellitus

566 All continuous characteristics are presented as mean \pm standard deviation. All categorical variables are presented as

567 total $\mathrm{n}($ column \%) in that category. 
CVD biomarkers and kidney function

Table 2. Biomarkers associated with eGFR and $\triangle$ eGFR in the FHS Offspring and Third Generation cohorts.

\begin{tabular}{|c|c|c|c|c|c|c|c|c|c|}
\hline \multirow[t]{2}{*}{ Protein biomarker } & \multirow{2}{*}{$\begin{array}{c}\text { Protein } \\
\text { biomarker } \\
\text { abbreviation }\end{array}$} & \multicolumn{2}{|c|}{$\begin{array}{l}\text { eGFR, } \\
\text { Offspring }\end{array}$} & \multicolumn{2}{|c|}{$\begin{array}{c}\text { eGFR, } \\
\text { Third Generation }\end{array}$} & \multicolumn{2}{|c|}{$\begin{array}{l}\Delta \text { AGFR, } \\
\text { Offspring }\end{array}$} & \multicolumn{2}{|c|}{$\begin{array}{c}\Delta \text { AeGFR, } \\
\text { Third Generation }\end{array}$} \\
\hline & & $\beta \pm \mathbf{S E}$ & FDR & $\beta \pm \mathrm{SE}$ & p-value & $\beta \pm \mathbf{S E}$ & FDR & $\beta \pm \mathbf{S E}$ & p-value \\
\hline Adipsin & -- & $-0.09 \pm 0.004$ & $<1 \mathrm{E}-27$ & $-0.04 \pm 0.002$ & $<1 \mathrm{E}-27$ & $-0.22 \pm 0.04$ & $7.3 \mathrm{E}-07$ & $-0.16 \pm 0.03$ & $1.2 \mathrm{E}-06$ \\
\hline Alpha-1-microglobulin & $\mathrm{A} 1 \mathrm{M}$ & $-0.06 \pm 0.004$ & $<1 \mathrm{E}-27$ & $-0.02 \pm 0.002$ & $3.5 \mathrm{E}-12$ & $-0.18 \pm 0.04$ & $1.1 \mathrm{E}-05$ & $-0.17 \pm 0.03$ & $3.6 \mathrm{E}-08$ \\
\hline Beta-2-microglobulin & B2M & $-0.10 \pm 0.004$ & $<1 \mathrm{E}-27$ & $-0.03 \pm 0.002$ & $<1 \mathrm{E}-27$ & $-0.43 \pm 0.04$ & $9.9 \mathrm{E}-21$ & $-0.13 \pm 0.03$ & $3.7 \mathrm{E}-05$ \\
\hline Cystatin C & -- & $-0.10 \pm 0.004$ & $<1 \mathrm{E}-27$ & $-0.04 \pm 0.003$ & $<1 \mathrm{E}-27$ & $-0.38 \pm 0.04$ & $6.8 \mathrm{E}-16$ & $-0.21 \pm 0.03$ & $1.8 \mathrm{E}-10$ \\
\hline $\begin{array}{l}\text { Epidermal growth factor } \\
\text { containing fibulin-like } \\
\text { extracellular matrix protein } 1\end{array}$ & EFEMP1 & $-0.05 \pm 0.004$ & $1.7 \mathrm{E}-26$ & $-0.01 \pm 0.003$ & 8.7E-4 & $-0.17 \pm 0.04$ & $2.8 \mathrm{E}-04$ & $-0.18 \pm 0.03$ & $1.6 \mathrm{E}-07$ \\
\hline Myoglobin & -- & $-0.07 \pm 0.004$ & $<1 \mathrm{E}-27$ & $-0.04 \pm 0.003$ & $<1 \mathrm{E}-27$ & $-0.20 \pm 0.04$ & $1.5 \mathrm{E}-05$ & $-0.13 \pm 0.04$ & 3.3E-04 \\
\hline $\begin{array}{l}\text { Soluble receptor for advanced } \\
\text { glycation endproducts }\end{array}$ & sRAGE & $-0.03 \pm 0.004$ & $3.0 \mathrm{E}-14$ & $-0.01 \pm 0.002$ & $6.4 \mathrm{E}-07$ & $-0.10 \pm 0.03$ & 0.02 & $-0.11 \pm 0.03$ & 9.4E-05 \\
\hline $\begin{array}{l}\text { Tissue inhibitor of } \\
\text { metalloproteinases } 1\end{array}$ & TIMP1 & $-0.06 \pm 0.004$ & $<1 \mathrm{E}-27$ & $-0.02 \pm 0.002$ & 4.4E-16 & $-0.21 \pm 0.04$ & $8.2 \mathrm{E}-06$ & $-0.14 \pm 0.03$ & $4.5 \mathrm{E}-06$ \\
\hline
\end{tabular}

570 Table 3. Causal inference results: MR results for biomarkers significantly associated with eGFR in cross-sectional analyses.

\begin{tabular}{|c|c|c|c|c|c|}
\hline Protein biomarker exposure & Protein biomarker abbreviation & $\begin{array}{l}\text { Kidney trait } \\
\text { outcome }\end{array}$ & $\mathbf{n}_{\text {snp }}$ & $\beta \pm \mathrm{SE}$ & p-value \\
\hline $\begin{array}{l}\text { Melanoma cell adhesion } \\
\text { molecule }\end{array}$ & MCAM & eGFR (continuous) & 1 & $-0.0111 \pm 0.0027$ & $5.11 \mathrm{E}-5$ \\
\hline $\begin{array}{l}\text { Epidermal growth factor } \\
\text { containing fibulin-like } \\
\text { extracellular matrix protein } 1\end{array}$ & EFEMP1 & eGFR (continuous) & 2 & $-0.0064 \pm 0.0016$ & $1.04 \mathrm{E}-4$ \\
\hline
\end{tabular}


CVD biomarkers and kidney function

$572 \quad$ Figure legends

573 Figure 1. Overview of the study design. 
Participants with SABRe CVD biomarkers

and kidney function measures

Study population

$$
(n=6,824)
$$

Offspring cohort

$(\mathrm{n}=2,873)$

Third Generation cohort

$(\mathrm{n}=3,951)$

\section{$\checkmark$}

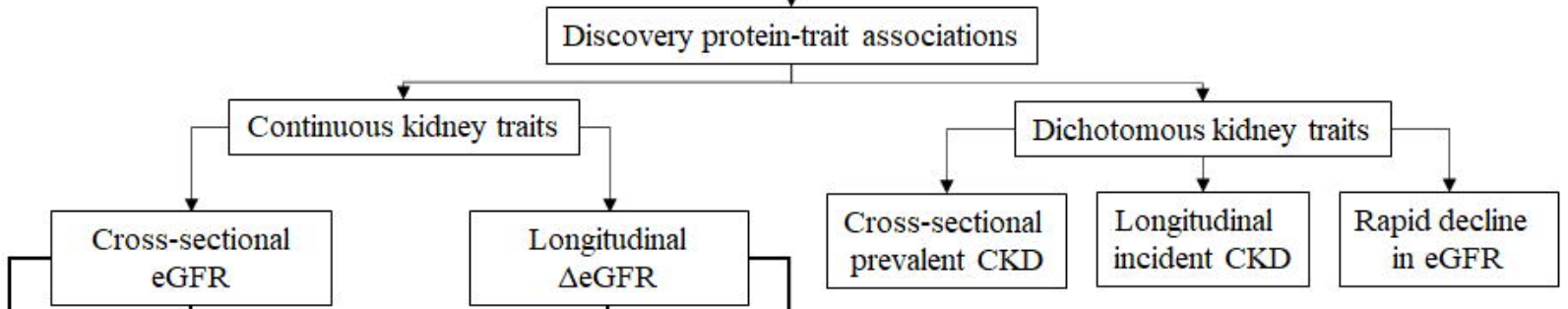

Protein-traitassociations 